\title{
Sandbar Breakwater: An Innovative Nature-Based Port Solution
}

\author{
Bart-Jan van der Spek ${ }^{1} *{ }^{\mathbb{D}}$, Eelco Bij ${ }^{1}{ }^{1}$, Bas van de Sande ${ }^{1}$, Sanne Poortman ${ }^{2}$, Dirk Heijboer ${ }^{1}$ \\ and Bram Bliek ${ }^{2}$ \\ 1 CDR International, 3818 HN Amersfoort, The Netherlands; e.bijl@cdr-international.nl (E.B.); \\ b.vandesande@cdr-international.nl (B.v.d.S.); d.heijboer@cdr-international.nl (D.H.) \\ 2 Svašek Hydraulics, 3024 ES, Rotterdam, The Netherlands; poortman@svasek.com (S.P.); \\ bliek@svasek.com (B.B.) \\ * Correspondence: bj.vanderspek@cdr-international.nl; Tel.: +31-6-4143-7344
}

Received: 3 April 2020; Accepted: 14 May 2020; Published: 19 May 2020

\begin{abstract}
The nature-based concept of the Sandbar Breakwater was born based on the typical natural dynamics of the West African coast (Gulf of Guinea). Learning from the development and coastal impact of the existing port infrastructure in West Africa, the application of sand as a construction material for marine infrastructure seemed very obvious. Along this coast, ports experience heavy sedimentation at the western updrift side of the breakwaters, leading to the rapid burying of valuable armour rock. The Sandbar Breakwater concept is based on this principle by using natural accretion as the basis for the port protection. Such a concept is advantageous as a large sediment drift naturally supplements the sand filling works during construction and the required rock volumes are reduced significantly, saving construction time and minimising the environmental impact. To counteract the downdrift coastal retreat, a replenishable sand engine completes the scheme. The realisation of a Sandbar Breakwater at Lekki, Nigeria, in 2018, with subsequent safe and continuous port operations, proves the feasibility of the concept. Sustainable future development is further pursued by integrated maintenance campaigns following the Building with Nature principles to guarantee the operability of the port while preserving the alongshore sediment balance and minimising the environmental impact.
\end{abstract}

Keywords: ports; breakwaters; coastal erosion; longshore sediment transport; nature-based solution; swell coast; West Africa; Sand Engine; Sandbar Breakwater

\section{Introduction}

The port sector is one of the most essential infrastructure sectors for West Africa [1]. Over the last two decades, the West African ports encountered a rapid increase in traffic, mainly comprised by containerised trade [2]. It has been estimated that between 2007 and 2017, USD 50 billion was invested in the African port sector and marine traffic has grown 7\% a year [3]. Further, due to China's increasing economic involvement in the development of the African continent, the port sector of West Africa will play a key role in the Asia-West Africa trade [4].

The coastal system of West Africa is highly affected by port development [5]. The West African coastline (mainly the Gulf of Guinea, from the Ivory Coast up to Nigeria,) is marked by its large unidirectional eastward sand transport induced by fairly constant and strong swell waves arriving from the Atlantic Ocean. The sand that originates from debouching rivers and large coastal sand deposits is interrupted by anthropogenic activities, such as river dams, sand mining and port infrastructure, such as breakwaters. Consequently, large parts of this coastline are eroding [6].

The increasing investments in the West African port sector will therefore inevitably aggravate the already fierce impact on the natural coastal system. This is further amplified by climate change: it is 
estimated that the effects of sea level rise on coastal erosion are of the same order of magnitude or even exceed the effects of the current major ports [6] (considering representative concentration pathway (RCP) 4.5 and RCP 8.5 respectively [7]).

This unique coastal zone will benefit from the development of resilient and sustainable port solutions. The implementation of nature- (or eco-) based solutions is an increasingly desired approach for coastal protection around the world [8]. However, port infrastructure, especially port breakwaters, have remained typically "grey", involving large quarried rocks, often combined with concrete units, to ensure sufficient calm harbour basins and approach channels. The Sandbar Breakwater concept (which includes a downdrift "Sand Engine" [9]) is a new innovative port solution that is nature-based, flexible, adaptive and thereby climate change resilient.

For the development of the large Dangote Refinery and Fertilizing Plant Project, that is currently under construction in Lekki, Nigeria, a few quays and a jetty with a RoRo facility needed to be developed for importing the construction materials and exporting the future products. To accommodate these logistics, this new innovative concept has been developed, designed and implemented, see Figure 1.

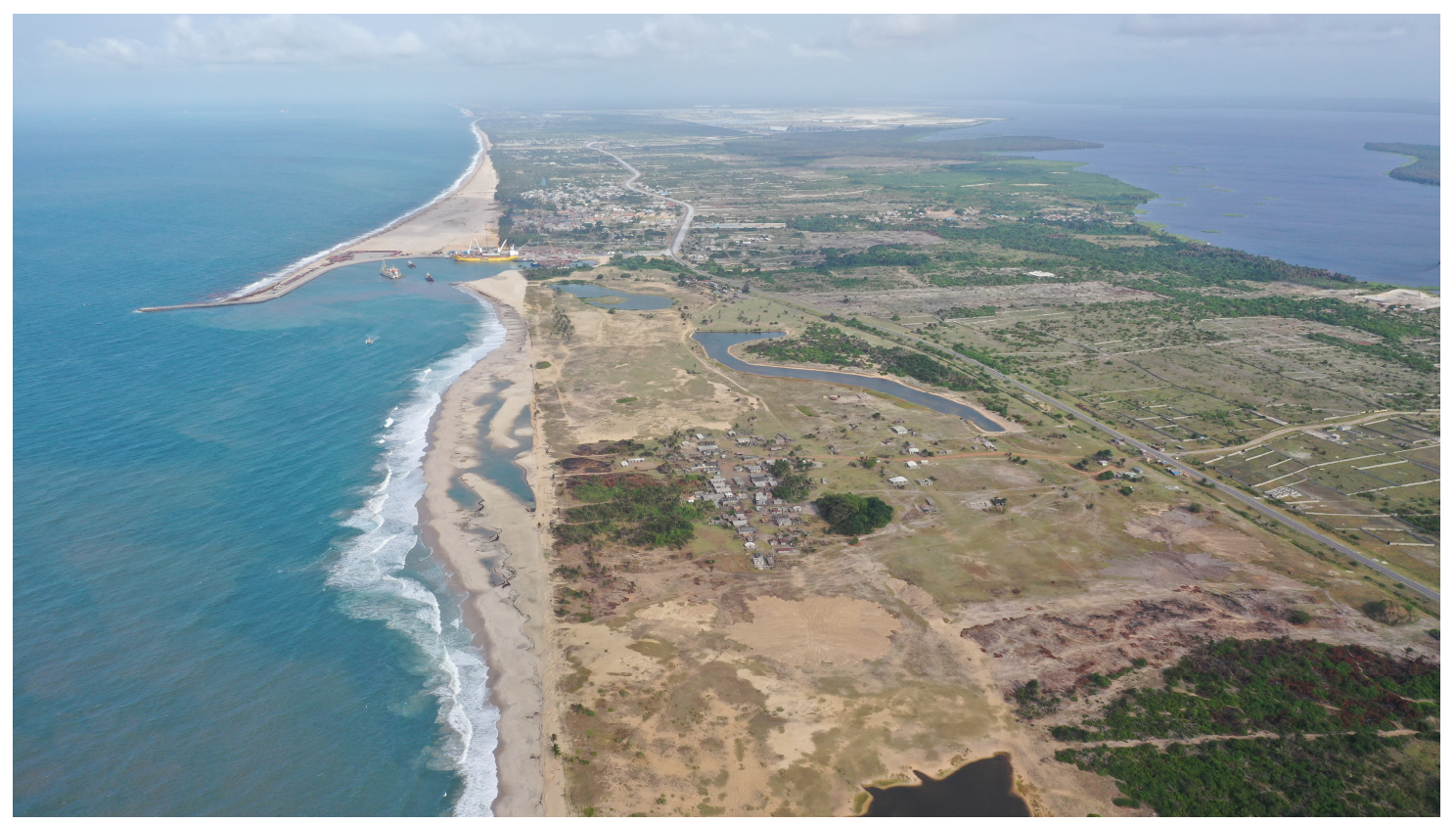

Figure 1. Westward looking aerial photo of the Sandbar Breakwater including the sand engine. Image courtesy of CDR International B.V.

\section{Field Site}

\subsection{The Coast of the Gulf of Guinea}

The coast along West Africa, especially at the Gulf of Guinea, can be defined as a "trailing edge" coast. The coastal zone is largely characterised by a barrier-lagoon complex [10]. The barrier-lagoon complex is a continuation of a system of barriers and lagoons covering the West African coast between Cote d'Ivoire and West Nigeria. This coastal stretch comprises low lying islands and narrow beach ridges aligned parallel to the coast, which are backed by creeks and lagoons. In this system, the upper geological strata consist of sediments which are generally medium to coarse and moderately well sorted [11].

The coast is subject to persistent strong swell waves. These swell waves are, in contrary to the local wind waves, generated by distant weather systems (storms) in the South Atlantic Ocean. The wave climate can be described as fairly uniform. Figure 2 shows the wave rose based on offshore hindcast data obtained from the NOAA NCEP WAVEWATCH III ${ }^{\circledR}$ Hindcast and Reanalysis Archives for the 
period February 2005-June 2019, for the location $6^{\circ} \mathrm{N}, 4^{\circ} \mathrm{E}$ (offshore off the coast of Lekki, Nigeria). From the wave rose, it is clear that the waves have a narrow directional bandwidth, predominately directed from the south-southwest.

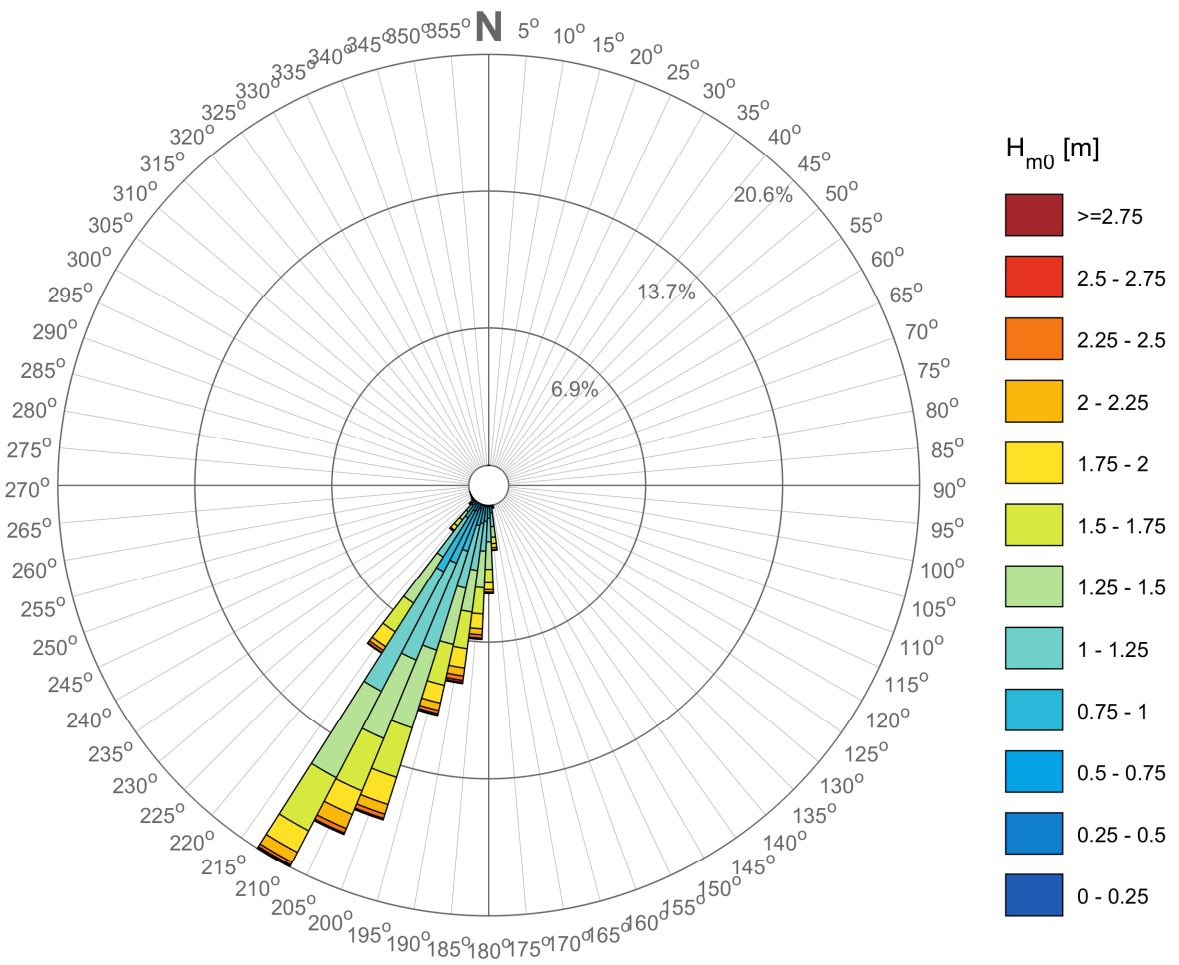

Figure 2. Wave rose based on offshore hindcast wave data from the NOAA WAVEWATCH III ${ }^{\circledR}$ Hindcast and Reanalysis Archives for location $6^{\circ} \mathrm{N}, 4^{\circ} \mathrm{E}$ (approximately $48 \mathrm{~km}$ off the coast) for the period February 2005-June 2019.

Figure 3 summarises the seasonal variation of the significant wave height and peak wave period for the same data. Although the wave height shows significant variation throughout the year with higher waves during the wet season (June-September), it persists strongly during the other months as it will never drop below $0.75 \mathrm{~m}$. The peak wave period remains uniform throughout the year and ranges between 10 and $16 \mathrm{~s}$ and may reach over $20 \mathrm{~s}$.

At Lekki, the waves break on a relative steep shore with a slope of 1:25-1:30 up to approximately the $-10 \mathrm{~m}+$ mean sea level (MSL) contour line, followed by a gentle slope of 1:100-1:500 along the coastal shelf of 30 to $40 \mathrm{~km}$ wide. The strong wave breaking induces a large unidirectional eastward longshore transport. At the coast of Lekki, Nigeria, it is estimated that the net eastward transport amounts to 650,000 to $1,000,000 \mathrm{~m}^{3}$ per annum, which is confirmed by other studies [11,12]. 


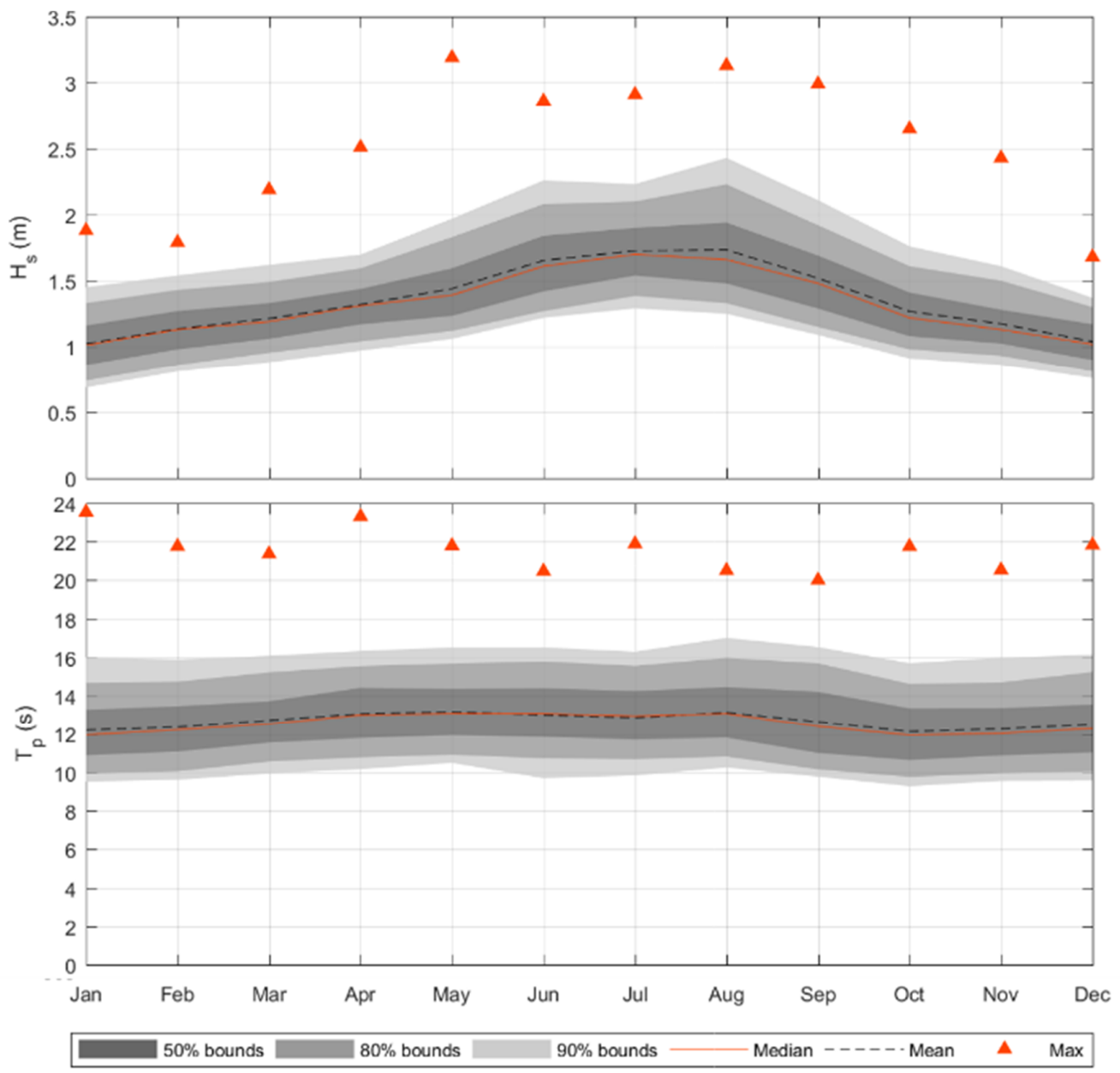

Figure 3. Seasonal characteristics' significant wave height and peak period, based on offshore hindcast wave data from the NOAA WAVEWATCH III ${ }^{\circledR}$ Hindcast and Reanalysis Archives for location $6^{\circ} \mathrm{N}$, $4^{\circ}$ E for the period February 2005-June 2019.

\subsection{The Lessons Learned}

The impact of port infrastructure has become very pronounced along many parts of the coastline of the Gulf of Guinea. In general, with a strong coastal advance on the updrift side (west) and continuous coastal erosion on the downdrift side (east).

East of the Cotonou Port, Benin Republic, strong structural coastal erosion has become an ongoing threat for coastal communities, of which a major part is caused by the port breakwaters [13]. The coastal erosion along the West African coast has been generally mitigated by hard coastal structures, such as groynes and some parallel breakwaters. Large groyne schemes downdrift of the ports of Cotonou and Lagos have locally stabilised the coastal retreat, but inevitably shifted the erosion further downdrift as the sediment balance remains disrupted. That is one of the typical downfalls of implementing any type of hard coastal structure in such a coastal environment.

The port of Lomé, Togo, also perfectly illustrates the effect of marine infrastructure and shows how ports continuously adapt accordingly. The southwestern breakwater of the port of Lomé has been finalised in 1967 [14] and since then, the adjacent coastline rapidly evolved.

Figure 4 shows three consecutive satellite images from Google Earth [15] of the port of Lomé for the years 2009, 2012 and 2016. The red line in the figures indicates the initial coastline before the construction of the port and is based on the work of [14]. Figure 4a shows that the coastline has advanced over almost $1 \mathrm{~km}$ towards the bend of the breakwater in 2009 (green line). Sketches in [14] however, suggest that the coastline reached the bend at least in 1992 or sooner. This may imply 
that the bypassing reached $100 \%$ prior to that time due to the fact the coastline has aligned with the orientation of the remaining breakwater. To prevent siltation of the navigation channel and the port basin, an additional spur has been constructed perpendicular to the breakwater preventing further sand bypassing (Figure 4b). Finally, the (partly) naturally accreted land has been used to accommodate the expansion of the port basin and the construction of new quays. As a result, the naturally formed sandbar has become the basis of the port protection, being kept in place by a single spur. At least a part of the cut volume of the basin was also used to fill the sandbar.
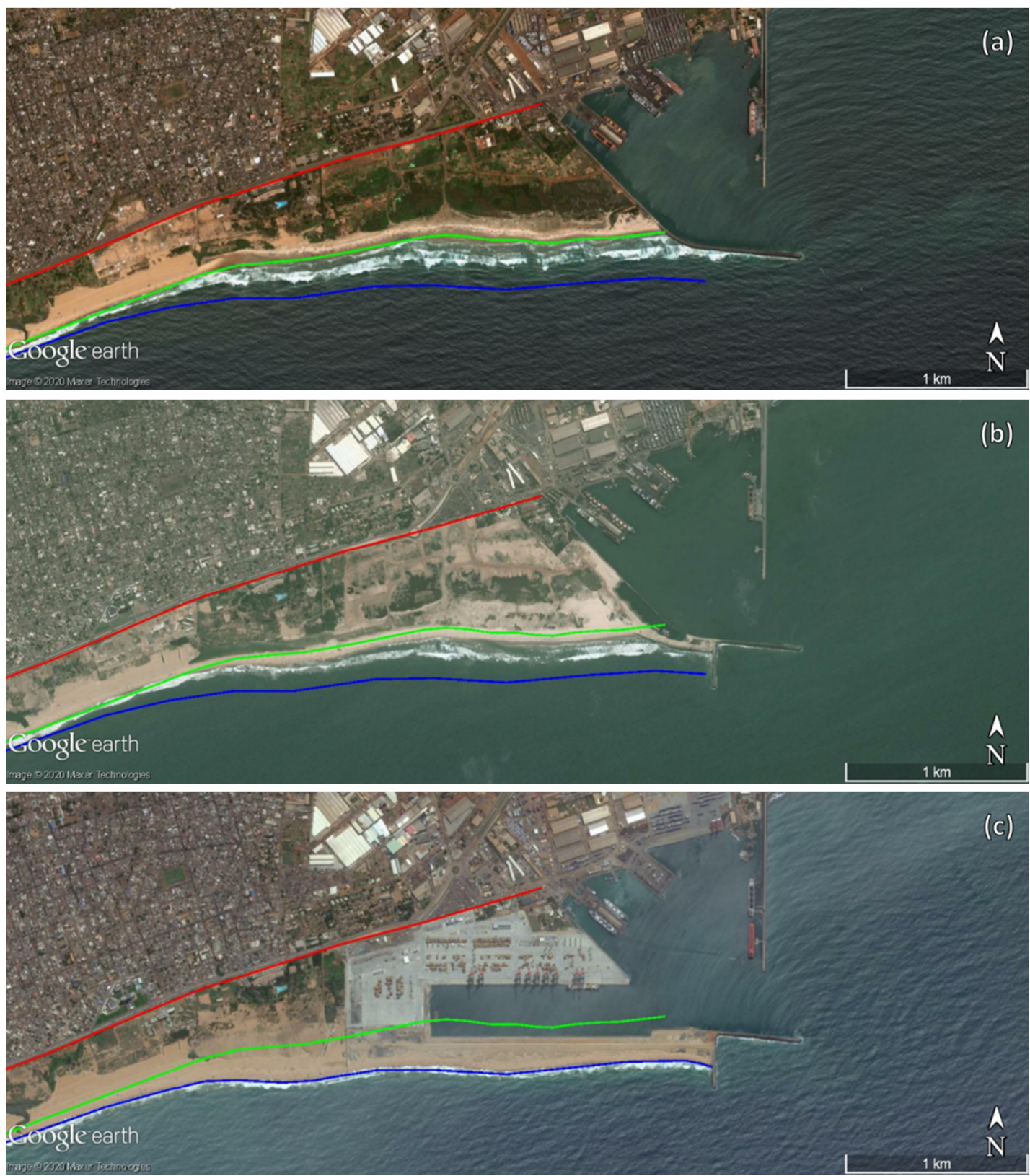

Figure 4. (a) Satellite image from 26 August 2009 from [15]. Red line: indicative coastline before start of construction of the breakwater around 1967 (based on figures in [14]), green line: coastline at moment of satellite image, blue line: coastline at moment of satellite image on 18 May 2016, (b) satellite image from 18 May 2012 from [15]. An additional spur has been constructed to prevent heavy bypassing and consequent siltation of the approach channel. (c) Satellite image: from 18 May 2016 from [15]. The accreted area is used for the port expansion and naturally a sandbar is created that forms the basis for the port protection. 
These examples show the huge impact that port infrastructure has on the local coastal dynamics, but on the other hand, particularly the development of the port of Lomé, provides inspiration to approach the design in a different way by taking nature as the basis and for pursuing a better sustainable management at the same time. The abundance of sand in the coastal system combined with the very uniform wave conditions have been the main components that triggered conceiving the concept of Sandbar Breakwater.

\section{Methods}

\subsection{Conceptualization}

On the basis of the typical natural dynamics of the coast of West Africa and the Gulf of Guinea in particular, the concept of the Sandbar Breakwater was born. Learning from the development and impact of the existing port infrastructure in West Africa, the application of ocean and shoreline sand as a construction material for port infrastructure seemed very obvious. Along the mentioned coast, all ports experience heavy sedimentation at the updrift side of the breakwaters, ultimately leading to the rapid burying of valuable armour rock. The conceptualization of the Sandbar Breakwater has been based on this principle by making the inevitable growing sandbar the basis for the port protection.

\subsection{Models and Engineering Methods}

For the design of the Sandbar Breakwater and its various components, several numerical models were used to assess the feasibility. For preliminary design purposes, a one-line coastline model—based on the theory of Pelnard-Considere [16] —is used to assess the expected coastline developments, especially the expected long-term downdrift effects. During the detailed design stage, the numerical morpho-dynamic model FineL $[17,18]$ is used to simulate the detailed (longshore) morphological developments in combination with the spectral wave model Swan [19]. Using these models, the coastline dynamics during construction, and (shortly) after construction, and the accretive behaviour during the first years after completion were predicted and investigated. This modelling exercise verified the design in relation to the alongshore sediment transport stability and expected accretion. The XBeach model [20] is used to assess the cross-shore erosion during extreme events, verifying the minimum sandbar width requirement and the design width during construction. For the assessment of the wave penetration, the wave model HARES [21] is used, based on the mild-slope wave equation.

The groyne structure at the tip of the sandbar was designed based on the guidelines of The Rock Manual [22] and the British Standards [23], formulae from Van Gent [24] and engineering expertise. Aspects in the structure stability for which no or limited design theories are available, including breaking waves on the beach slope and future siltation around the breakwater head, were specifically investigated during the extensive 3D physical model testing. The final design was verified using this 3D physical model testing by applying the relevant design wave and overload conditions in the scale model.

\section{Results}

\subsection{Overall Concept}

The key element of the Sandbar Breakwater concept is a sand body orientated close to its equilibrium, and held in place by a groyne structure at the tip of the sandbar, see Figure 5. The Sandbar Breakwater is morphologically dynamic from the start of construction, and eventually the coastline and related beach profiles reshape to a (dynamic) equilibrium. The associated time scale of its implementation matches the natural coastal response timescale. The concept thereby makes optimal use of its natural character and the abundant locally available sand and minimises the use and installation of hard construction materials, viz., rocks and concrete armour units. 


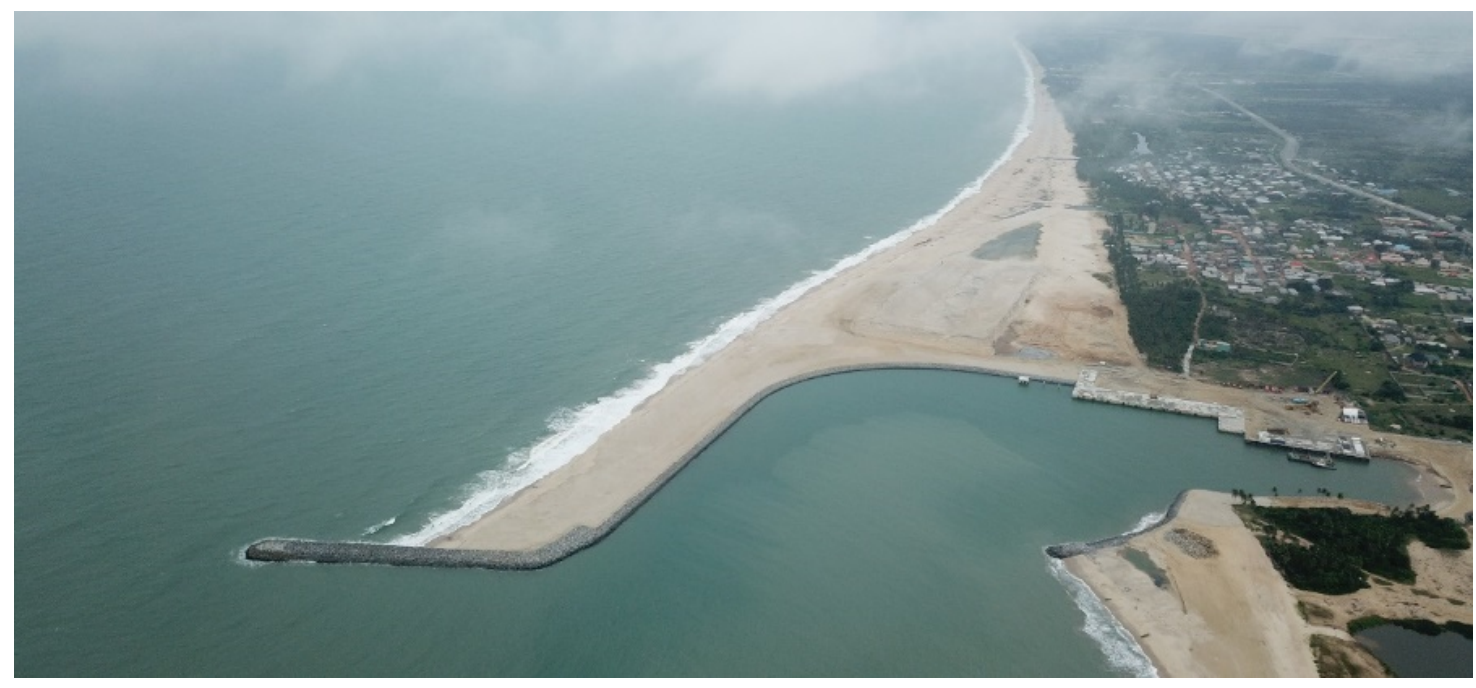

Figure 5. Westward looking aerial photograph of the Sandbar Breakwater at Lekki, Nigeria, a couple of months after construction (image courtesy of CDR International B.V.).

The Sandbar Breakwater concept balances the sand and rock quantities: as sand forms the basis of the breakwater, the use of rock and concrete units is significantly reduced compared with a conventional breakwater. In general, such hard construction materials are relatively expensive and need to be quarried and transported over often large distances and narrow or congested roads. Along this coastline, sand is abundantly available, which can be safely sourced. It is an attractive construction material due to its low costs and quantities, and can easily be scaled by increasing the number of hopper dredgers.

The initial sand body volume is minimised to make optimal use of the ongoing import of sand, reducing the total required construction material. The Sandbar Breakwater in Lekki, Nigeria, had consequently significantly lower construction costs and a significant increase in its construction speed, which was vital for the feasibility of the project. This has also led to a minimisation of quarrying (i.e., blasting, sorting, etc.) and truck movements (75\% to $85 \%$ ) through the Lagos State road network, in turn minimising congestion, traffic accidents, nuisance, impact on air quality and the carbon footprint.

As sand can be easily re-handled, this new concept is flexible and allows for a relatively easy future port expansion: the (partly) naturally accreted area in the west may accommodate the expansion of the harbour basin, like happened at the port of Lomé, Togo (see Figure 4). The constructed Sandbar Breakwater in Lekki has an already planned expansion of the harbour basin starting in 2020. Initial construction works for the expansion of the basin are shown in Figure 6. Further, the soft character and the flexibility of the concept makes the Sandbar Breakwater more resilient and adaptable to climate change, compared with a conventional breakwater scheme.

Any obstruction of the longshore sediment transport, albeit a conventional breakwater, groyne, revetment or a Sandbar Breakwater, will inherently lead to downdrift erosion. Hard structures will always shift the problem downdrift and eventually will not mitigate the net effect. The most natural way to mitigate this impact is by restoring the natural sand balance. Therefore, a "Sand Engine" [9] (local nourishment) has been implemented in the concept to mitigate the coastal retreat downdrift. As erosion continues, this sand engine requires repetitive nourishment to stabilise the coastline.

The concept of the Sandbar Breakwater and the accompanying sand engine are complementary with regards to sustainability and are therefore considered to be inseparable within the overall concept, especially within such a coastal environment with a strong unidirectional transport.

The Sandbar Breakwater was successfully realised in the first half of 2018 in less than five months and since September of 2018, the port facility is in operation. 


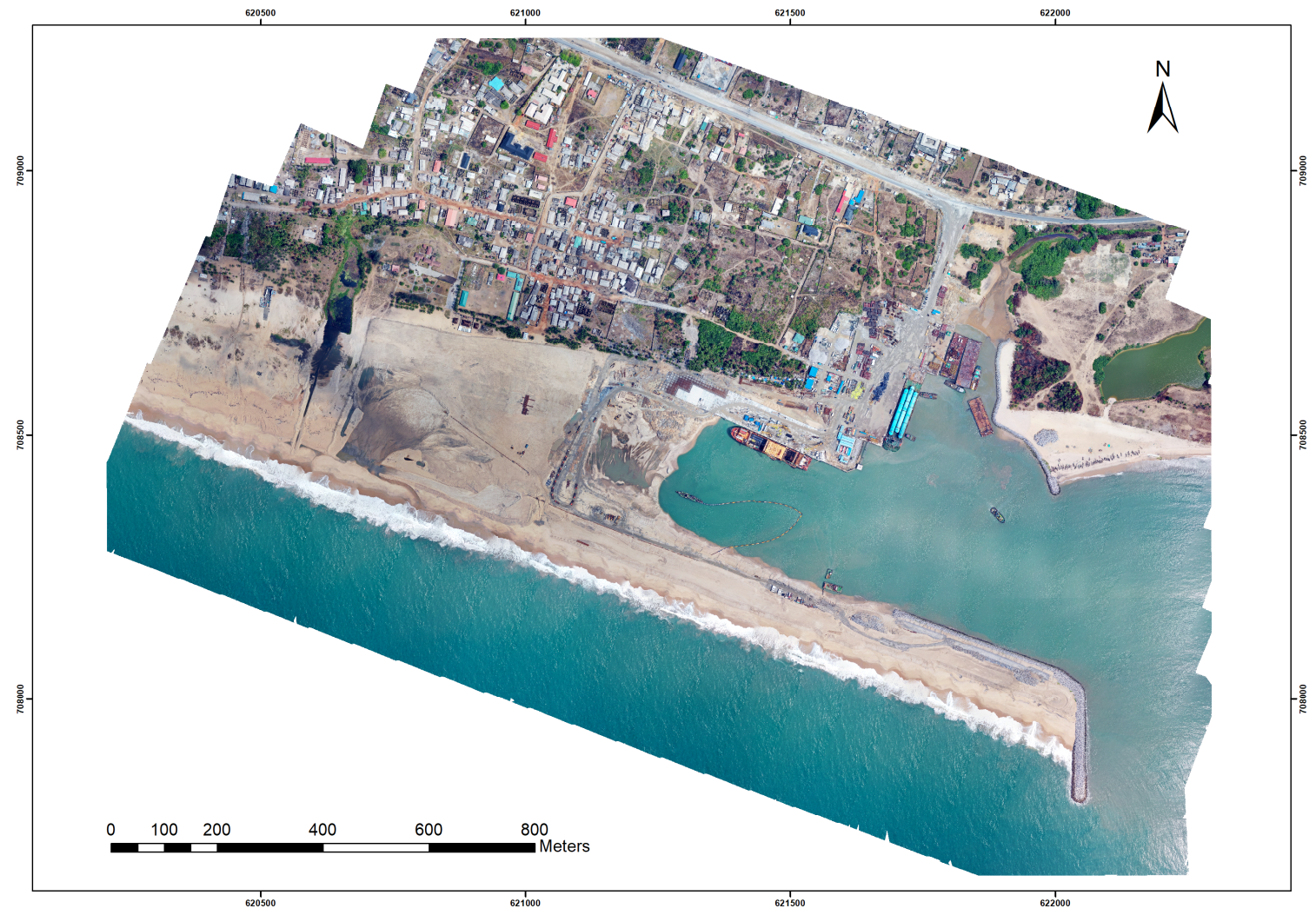

Figure 6. Orthophoto of March 2020, showing the ongoing expansion of the port basin. Image courtesy of CDR International B.V.

\subsection{Design Components}

The design of the Sandbar Breakwater consists of the following main components which are briefly described separately: (i) sandbar body, (ii) sandbar groyne and (iii) sand engine.

\subsubsection{Sandbar Body}

In an iterative way, a sustainable and optimal design of the sandbar body has been attained. The design of the sandbar body essentially entails the design of the initial shape of the sand body that is required for the construction and for the expected reshaping that will lead to a dynamically stable coastline without the risk of breaching in the initial years after construction. The required initial shape (and thus sand volume) is therefore dependent on the expected equilibrium orientation of the local coastline and the distribution of the sand fill along the upstream coast.

As a first step, the equilibrium coastline orientation has been estimated by calculating the S- $\varphi$ curve, which shows the relation between the yearly longshore sediment transport (S) and the local coastline orientation $(\varphi)$. The bulk longshore sediment transport formula of van Rijn [25] is used, which reads as follows:

$$
S_{\text {mass }}=0.0006 K_{\text {swell }} \rho_{s} g^{0.5}(\tan \beta)^{0.4}\left(d_{50}\right)^{-0.6}\left(H_{s, b r}\right)^{2.6} V_{\text {wave }}
$$

where $V_{\text {wave }}$ is the wave-induced longshore current velocity $(\mathrm{m} / \mathrm{s})$ averaged over the cross-section of the surf zone and is calculated with

$$
\mathrm{V}_{\text {wave }}=0.3\left(g H_{s, b r}\right)^{0.5} \sin \left(2 \theta_{b r}\right)
$$


where the wave parameters at the breaker line $\left(H_{s, b r}, \theta_{b r}\right)$ are calculated using the nearshore wave parameters using

$$
\begin{gathered}
\mathrm{H}_{s, b r}=\gamma h_{b r} \\
\sin \theta_{b r}=\left(c_{b r} / c_{n}\right) \sin \theta_{n}
\end{gathered}
$$

where $h_{b r}$ is the water depth at the breaker line (location where $5 \%$ of the waves are breaking), which is estimated using

$$
h_{b r}=\left(\frac{H_{s, n}^{2} c_{n} \cos \theta_{n}}{\alpha \gamma^{2} g^{0.5}}\right)^{0.4}
$$

where:

- $S_{\text {mass }}$ : total longshore sediment transport $(\mathrm{kg} / \mathrm{s})$. A bulk density of $1600 \mathrm{~kg} / \mathrm{m}^{3}$ is used to convert this to $\mathrm{m}^{3} / \mathrm{s}$;

- $\quad K_{\text {swell }}$ : swell factor $=0.015 p_{\text {swell }}+\left(1-0.01 p_{\text {swell }}\right)$, where $p_{\text {swell }}$ is the percentage of swell wave heights, which is considered $100 \%$ at this location;

- $\rho_{s}$ : sediment density $=2650 \mathrm{~kg} / \mathrm{m}^{3}$;

- $\tan \beta$ : slope of surf zone = 1:20;

- $d_{50}$ : median grain size $=600 \mu \mathrm{m}$ (based on sediment samples [26]);

- $H_{s, n}, \mathrm{H}_{s, b r}$ : significant wave height nearshore (at $10 \mathrm{~m}$ water depth) and at the breaker line (m);

- $\theta_{n}, \theta_{b r}$ : wave incidence angle (to shore normal) nearshore (at $10 \mathrm{~m}$ water depth) and at the breaker line;

- $\quad g$ : acceleration of gravity $\left(\mathrm{m} / \mathrm{s}^{2}\right)$

- $\quad \gamma$ : breaker coefficient (based on $5 \%$ breaking) $=0.6$;

- $\quad c_{n}, c_{b r}$ : wave celerity nearshore (at $10 \mathrm{~m}$ water depth) and at the breaker line (m/s). Determined by iteration using the dispersion relation;

- $\quad \alpha$ : calibration coefficient $=1.8$.

The nearshore wave conditions were calculated using the spectral wave model SwAN at a depth of $10 \mathrm{~m}$ in front of the Lekki coast using the offshore hindcast wave and wind data as described above as the input. The yearly longshore sediment transports have been calculated using a nearshore timeseries for a range of coastline orientations.

Figure 7 shows the resulting S- $\varphi$ curve with the blue dashed line indicating the initial coastline orientation, being around $100^{\circ} \mathrm{N}$, with an average net eastward longshore transport of around $850,000 \mathrm{~m}^{3}$ per annum. The equilibrium orientation $\left(=0 \mathrm{~m}^{3}\right.$ per annum $)$ is calculated to be approximately $112.5^{\circ} \mathrm{N}$ (green dashed line). This illustrates the high sensitivity of the coastline orientation to the net longshore sediment transport, especially around its equilibrium.

Although the net sediment transport along the main part of the sandbar should be minimised, it is considered that this net transport should always be directed eastward to prevent erosion of the sandbar, especially during the first years after construction and years with more southerly wave directions than the long-term wave climate. That is the reason why the initial orientation near the groyne of the design profile of the sandbar body has been set to $110^{\circ} \mathrm{N}$ (red dashed line) to ensure eastward transport and to accommodate any uncertainty related to the dominant offshore wave direction. This orientation has been used as the starting point in the design of the sandbar body.

Essentially, with respect to its stability, the optimal initial sandbar shape is such that it is as close as possible to the natural equilibrium shape, preventing large initial longshore gradients. Large longshore gradients will lead to a strong and immediate reformation of the sand body and to potentially significant erosion at the weakest parts where the natural import capacity is insufficient to prevent erosion of the sandbar. It therefore does require a sufficient initial sand buffer to accommodate for reshaping, whilst preventing breaching and ensuring adequate protection of the port basin. 


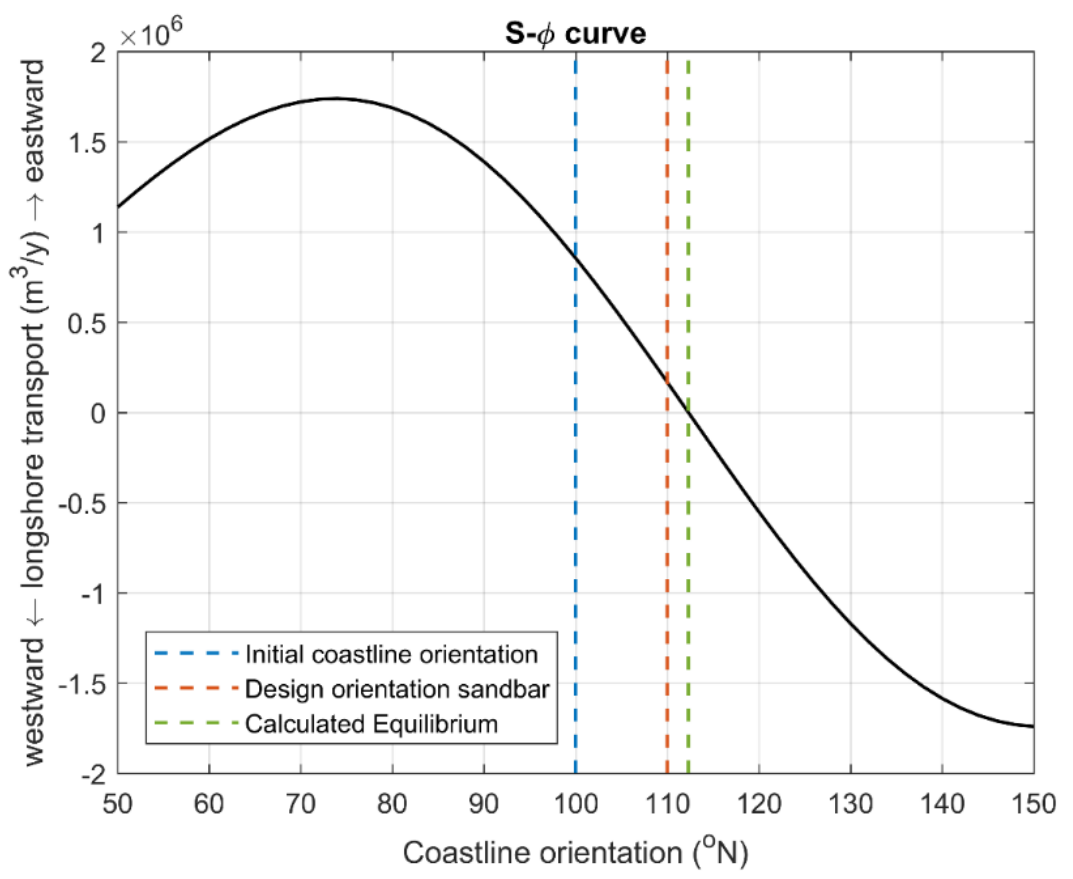

Figure 7. Calculated S- $\varphi$ curve at the project site, Lekki, Nigeria.

Subsequently, the determination of an optimal initial geometry of the sand formation to be placed actively involved several iterations to both minimise the sand buffer volume and ensure the sufficient overall stability of the breakwater. For each iteration, the shape was adjusted and the stability was verified with a calibrated 2DH numerical morphodynamic Finel-Swan model, see Appendix A for details.

It appeared that the shape (red outline) as shown in the satellite images in Figure 8 is the most optimal design and minimises the risk of a breaching of the sandbar. Figure 9 shows the results of the Finel model for the final design. Since the outer coastline is essentially determines the amount of reshaping, the inner volume could be reduced by creating a small inner lake. It is noted that during the Lekki project, this lake has been filled with sand to use as a stockpile for other construction projects upon the request of the client.

In the first year, the sandbar width reduces due to the reshaping of the sand body. This means that the most critical moment, in which the sandbar width is the smallest, is expected at approximately one year after construction. The ongoing natural accretion from the west ensures that the erosion rates of the sandbar reduce with time and a stable situation is expected in the years after.

The uniformity of the wave climate leads to a generally good predictability of the longshore morphological developments and made it possible to make a robust design for the sandbar body. This was crucial for the successive implementation of the design. Further, Moesker N. [27] concluded that the natural variability of the wave climate (especially directional variability) does not significantly affect the stability and the viability of the Sandbar Breakwater concept in this coastal environment.

Most of the morphological development occurs during the wet season because the waves are more energetic during that period (see Figure 3), inducing significantly more transport. Hence, the reshaping of the sandbar is visibly very pronounced in Figure $8 c$, taken only 9 months after the construction of the sandbar body. The coastline has shifted rapidly towards the equilibrium orientation as expected and predicted by the numerical models.

It is emphasized that the construction of the groyne needed to start very soon to fix the eastern end of the sandbar and prevent the eastward loss of sediment. For this reason, firstly a bund has been reclaimed directly to the northern tip of the groyne to ensure a proper land connection in order to start the construction of the groyne. Thereafter, the westward sandbar body has been reclaimed. 

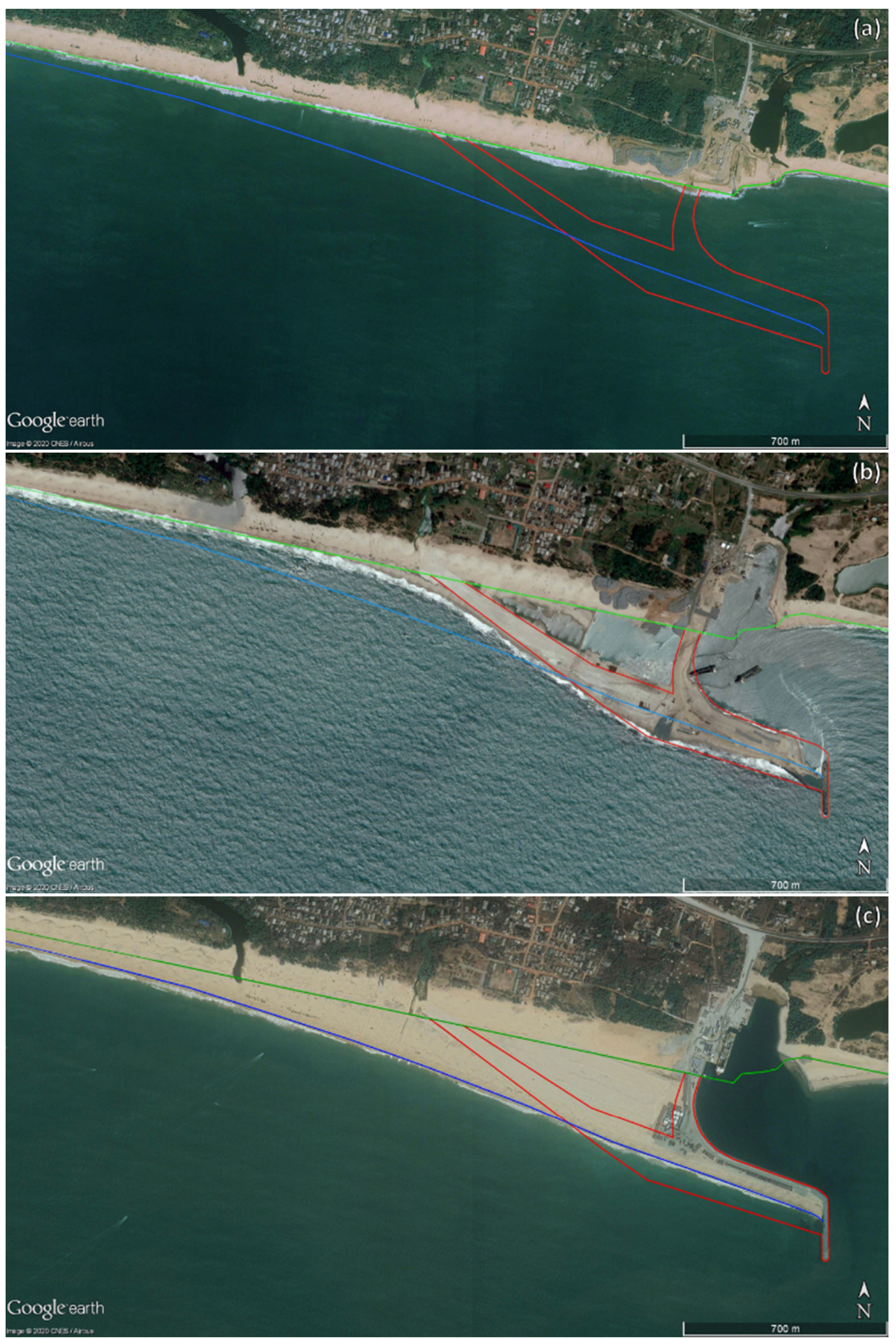

Figure 8. (a): Satellite image from 25 December 2017 from [15], showing the coastline just before construction (green line). (b) Satellite image from 06 March 2018 from [15], showing the situation just after the sandbar body has been put in place according to the design (red line), (c) satellite image from 24 December 2018 from [15], showing the resulting reshaping after a wet season and the coastline reaching the equilibrium coastline orientation as expected (blue line). 

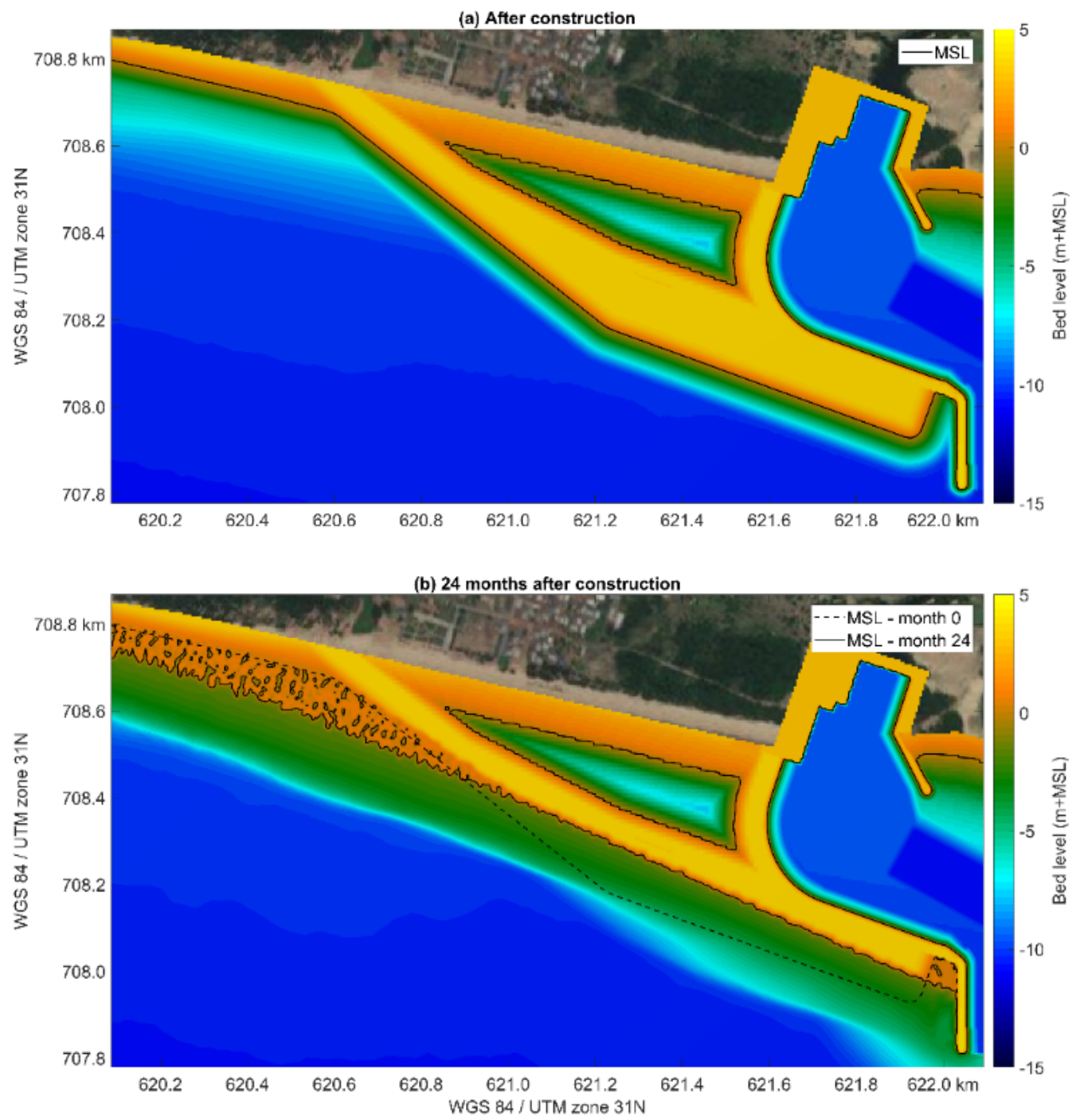

Figure 9. FINEL-SwAn results. (a) Bed level during the final construction stage of the Sandbar Breakwater. (b) Bed level after 2 years of morphological simulation for the final design.

The risk of breaching during extreme wave events has been verified using the separate XBeach model to assess the expected cross-shore development. This model is capable of simulating the relevant cross-shore processes that are important during strong wave conditions. It is noted that in this area, there are no "storms" present that are defined by a low-pressure field and accompanied by high wind speeds. That is the reason why the extreme wave heights (e.g., those with a return period of 100 years) are not exceptionally higher than the yearly wave conditions.

It was estimated that during extreme wave events with a return period of one year, a coastal retreat of approximately $15 \mathrm{~m}$ at the mean sea level (MSL) may occur. It is assessed that this retreat is recovered soon due to the longshore processes, which are in this case dominant. There is also no visible evidence (e.g., based on satellite images) of a structural coastal retreat after extreme events along the Lekki coastline.

Sufficient calibration data, such as consecutive cross-shore profiles before and after extreme events, were lacking and hence the calculated cross-shore retreat due to extreme events was relatively uncertain. That is the reason why the minimum required sandbar width accommodated for additional adverse events and has been set to $60 \mathrm{~m}$ (at MSL). 


\subsubsection{Sandbar Groyne}

At the tip of the sandbar body, a rock groyne structure is required to fix the sandbar and to block the alongshore sediment transport. The length and orientation are the key parameters for the design of the groyne, as these determine the effective blockage length (and hence the total groyne length and costs) and its performance against wave penetration into the port basin. The effective blockage length of the groyne affects the timing and magnitude of future sand bypassing.

Although the effective blockage length is shorter compared with a shoreline perpendicular structure, a north-south orientation of the groyne was found to be most effective, especially with respect to wave sheltering, due to the following benefits:

- An additional diffraction point has been created for the most dominant wave direction $\left(\sim 200^{\circ} \mathrm{N}\right)$, providing additional sheltering;

- Wave energy running along the groyne is being absorbed along the structure due to the refraction of the waves on the slope, resulting in reduced wave energy entering the port basin.

At Lekki, the local swell wave climate is dominantly directed from the south-southwest. However, occasionally, swell also occurs from the south $\left(180^{\circ} \mathrm{N}\right)$ or even more easterly. As such, this orientation also provides some sheltering for the southern waves due to the above phenomena. The effect of the wave sheltering is visualised in Figure 10 below, showing the computed wave field around the Sandbar Breakwater for a normative wave condition with the predominant wave direction: wave height of $1 \mathrm{~m}$, wave period of $12.5 \mathrm{~s}$ and a wave direction of $210^{\circ} \mathrm{N}$. The wave field is computed using the HARES software [21].

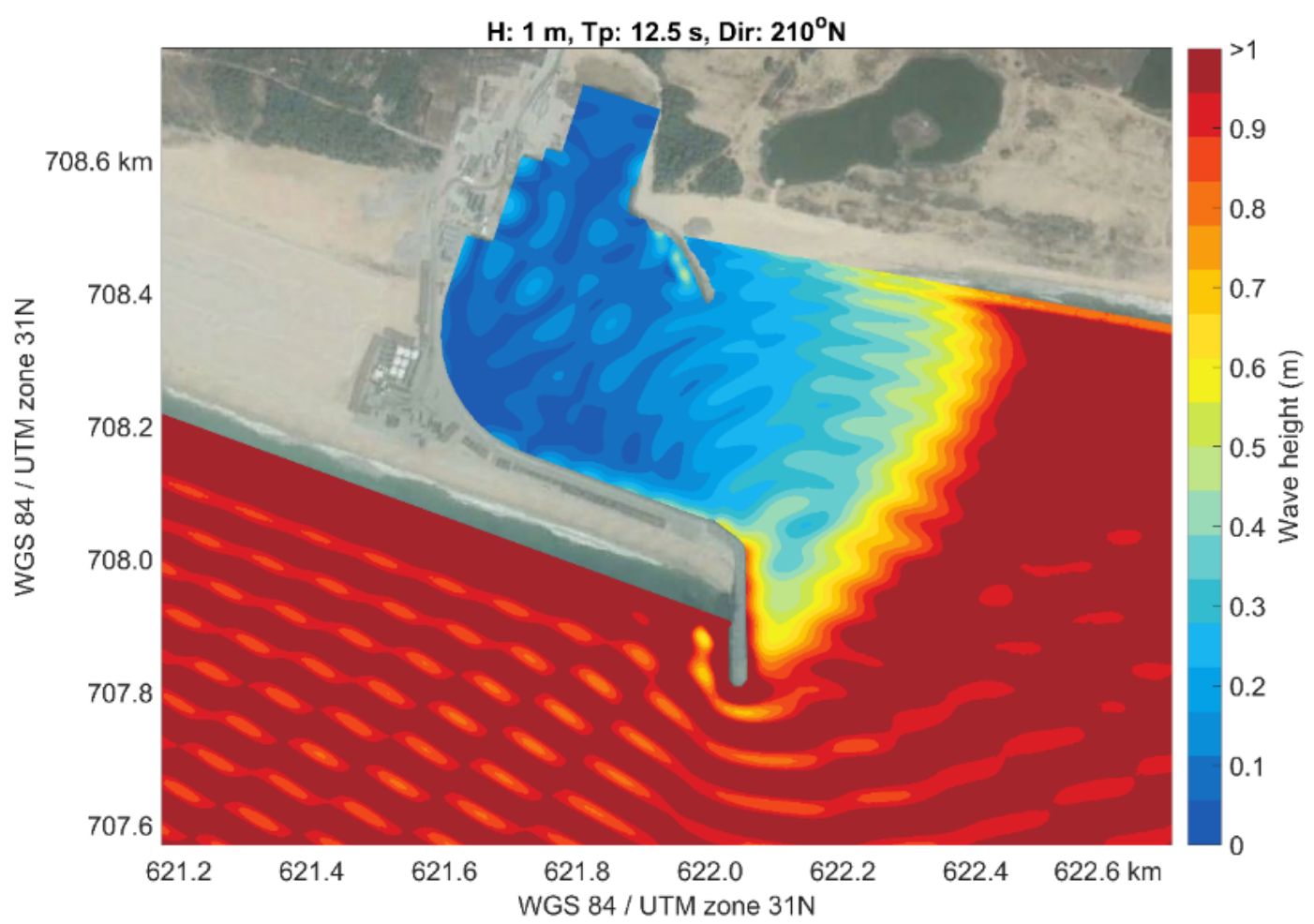

Figure 10. Wave penetration calculation with the HAREs software showing the calculated wave height in colors for the offshore condition of wave height of $1 \mathrm{~m}$, (peak) wave period of $12.5 \mathrm{~s}$ and wave direction of $210^{\circ} \mathrm{N}$.

It can be observed that the main diffraction point is located at the southern tip of the groyne and the second point at the rear part, resulting in significantly lower wave energy at the entrance and the basin of the port. Eventually, it may be argued that the resulting sheltering performance of the Sandbar 
Breakwater concept is better compared with a conventional rubble-mound breakwater alternative, considering similar dimensions of the protected port basin.

The groyne armour consists of interlocking concrete armour units at the tip and along the west (exposed) part of the trunk. Along the east trunk and on the crest, rock material with a grading of 1 to 3 tons was found to be stable due to the oblique arriving waves [24]. This design was verified to function in accordance within the design requirements by 3D physical model testing. This included overload testing, for which the structure remained stable, and testing for an increased bed level at the tip of the groyne, causing increased shoaling and wave breaking, due to future expected siltation.

The construction planning and methodology was considered in the design and optimisation of the groyne structure. Sand material was included in the groyne body as much as possible, whilst assuring that along the exposed areas the rock body would reach the original seabed.

Rock savings were obtained by bottom-dumping sand material to form a heightened sand foundation for the groyne structure, where the footprint of the sand slope remained within the groyne footprint, and by placing sand material of the sandbar partially in the main body of the groyne in its northern section. The latter was possible as the skeleton of the sandbar body was placed first, enabling to reach the groyne structure over land. The final transition between the sandbar under construction and the commencement of the groyne construction consisted of a quarry run bund, protected at the seaside with armour rock, which also functions as hidden sleeping protection for a potentially weak section of the sandbar.

\subsubsection{Sand Engine}

The unavoidable erosion downdrift is mitigated by repetitive yearly nourishments in the form of a small-scale sand engine. Without any mitigation, a coastline retreat of $100 \mathrm{~m}$ can be expected in one year's time, as follows from an analysis with a one-line coastline model, see Figure 11.

The most important design parameters of the sand engine are the required volume and its anticipated design life. To limit the spatial extent of the sand engine and thereby ensuring that the nautical approach of the port remains undisturbed, the design life is set to one year. To account for the erosion expected in one year, the sand volume applied in the sand engine should be at least equal to the expected yearly undisturbed longshore sediment transport capacity, being $850,000 \mathrm{~m}^{3}$ of sand. Practically, a larger volume has been implemented to account for the yearly variation.

The effectiveness of several shapes of the sand engine is investigated by means of the FINEL-SwAN model. It can be concluded that the shape, although reasonably spread along the coastline, does not significantly affect its behaviour, and mainly that the fill volume determines the ability to counter the coastline retreat for one year. An indication of the implemented sand engine formation is shown in the aerial photograph in Figure 1.

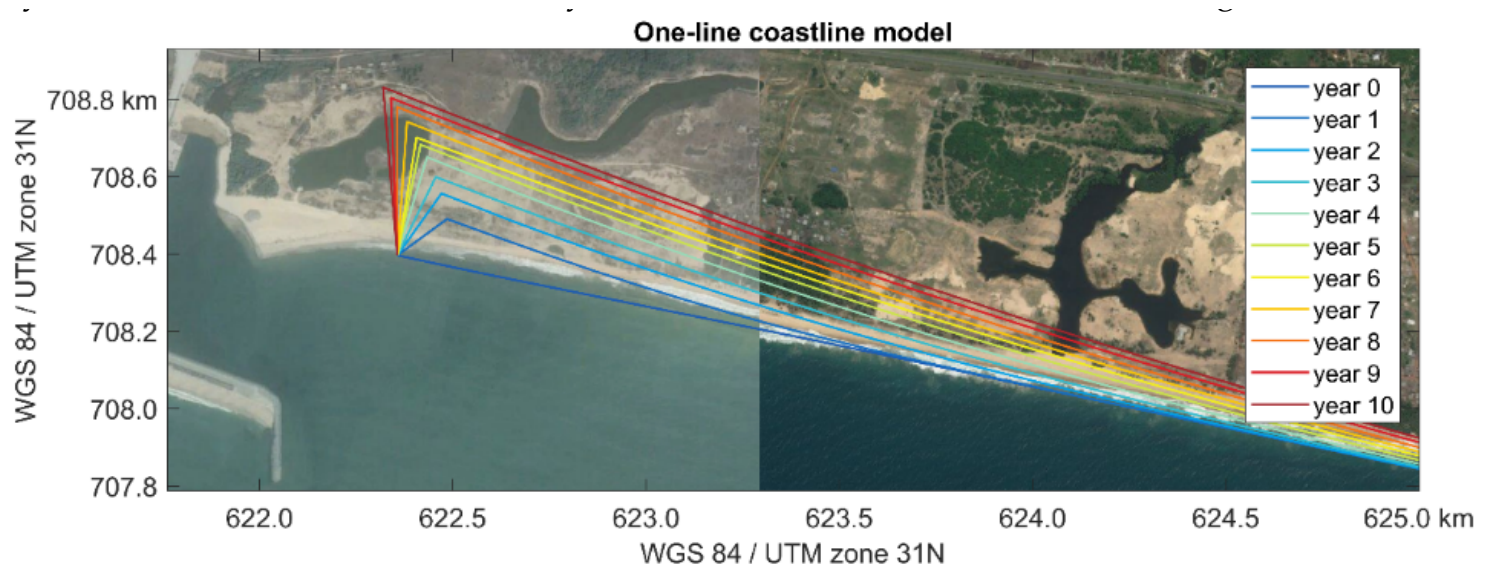

Figure 11. Simulated coastline development at the eastern side of the port after the construction of the Sandbar Breakwater using a one-line coastline model. 


\section{Discussion}

\subsection{Impact of Updrift Interventions}

We have learnt that any type of hard marine infrastructure along this coastline will have a major impact. The influence of such structures, in terms of erosion and accretion, spreads rapidly along the coastline and gradually slows down over time. This influence zone may reach the order of kilometres along the coastline in both directions, depending on the shore perpendicular length of the structure (order of tens to hundreds of metres). The structural integrity of a Sandbar Breakwater relies on an undisturbed updrift longshore sediment transport. Adverse coastal impact in the updrift influence zone of a Sandbar Breakwater might jeopardize the stability of the sandbar. Special attention is therefore required in case other (port) marine infrastructure is planned in the vicinity of a Sandbar Breakwater. Fortunately, the mutual distance between ports is generally in the order of hundreds of kilometres and hence it is considered that it does not pose an immediate showstopper to the application of this concept for this type of coastline.

\subsection{Maintenance and Long-Term Effects}

Maintenance is an inherent part of port operations and management and is key to ensure the long-term functioning of the concept. The main long-term effects of a Sandbar Breakwater are comparable with a conventional breakwater: continuous accretion will eventually lead to the siltation of the access channel and basin and coastal erosion will continue at the lee-side.

The maintenance of the access channel, Sandbar Breakwater and sand engine should be done in an integrated manner, serving the operability of the port as well as to preserve the alongshore sediment balance along the Lekki coastline as much as possible. By doing so, three considerable risks can be mitigated, namely (i) the breaching of the sandbar, (ii) the siltation of the access channel and the harbour basin and (iii) downdrift erosion.

The risk of breaching is linked to the weakest parts of the sandbar: the parts with minimal buffer. Alongshore or cross-shore erosion during a strong wave attack may lead to unsafe situations if the sandbar body is not sufficiently wide. Due to its dynamic character, the sandbar's width and height should be monitored, especially in the first years after construction. A minimum required width at different levels has been defined as a critical limit for applying maintenance to ensure a sufficient body. Maintenance can then be performed relatively easily by placing or moving sand to the most critical locations either by waterborne but preferably by land equipment. The latter illustrates the flexibility in strengthening the sandbar and thereby the high resiliency or adaptability to long-term climate change-induced impacts.

The siltation of the access channel and basin is expected to be dominated by the bypassing of sediment along the groyne, which in the long term is inevitable. Siltation of the access channel and harbour basin, caused by sand bypassing, can best be mitigated by a (semi) continuous active bypassing of sand to the lee-side of the scheme, thereby mitigating the risk of coastal erosion at the same time.

Further research is needed in finding solutions to actively or passively bypass accreted sand on the sandbar to the sand engine. There are several active sand bypassing systems operational around the world, for example, the bypass system at the Tweed River, Australia [28]. It is, however, noted that the integrity of the sandbar should not be jeopardised, meaning the amount of bypassing needs to be controlled accurately to prevent a negative sand balance at the sandbar.

In any case, it is envisaged to utilise the bypassed material for the replenishment of the sand engine. The amount and expected timing of the bypassing can be influenced in the design by changing the groyne length, or by increasing the groyne length at a later stage when required.

The maintenance of the Sandbar Breakwater, the access channel and the sand engine should be framed following a long-term vision in which the maintenance requirements of each coastal/port element are adjusted to each other. An acceptable minimum width of the sandbar, a minimum available water depth in the access channel and a maximum allowable downdrift annual coastal retreat could 
be the basis for such specifications. By linking the various requirements, the alongshore sediment balance is automatically incorporated in a maintenance chain. Before sand bypassing takes place, the perpetual replenishment of the sand engine needs to be performed by the import of sand from elsewhere, viz., offshore. However, from the moment sand bypassing occurs, the expected siltation of the access channel and port basin can be actively removed and deposited again in the sand engine, thereby following the natural movement of the sand from the same source.

In order to be able to specify and periodically update a maintenance plan, the regular monitoring of the coastline position, bathymetry and topography is required and is of paramount importance.

\subsection{Impact of Dredged Access Channel}

One of the criticalities that needs attention in this concept is the inclusion of a dredged access channel. At Lekki, the existing bathymetry provided sufficient depth for the access of the design vessels and hence no access channel outside the scheme needed to be dredged. However, it is well known that dredged channels can have a major impact on the local wave climate, especially in such a wave climate with uniform long period swell waves [29]. The Sandbar Breakwater concept necessitates an alongshore uniform wave climate to prevent an unexpected coastline deformation or structural erosion of the sandbar that may increase the risk of breaching. An appropriate channel alignment can prevent an undesired alongshore disturbance of wave energy caused by wave reflection or refraction along the channel.

\section{Conclusions}

The successfully designed and implemented Sandbar Breakwater at the coast of Lekki, Nigeria, showed that this concept is a cost-effective and quickly buildable port protection. By using the typical local natural dynamics as the starting point for the evolution of this concept, it follows the principles of Building with Nature $[30,31]$ and is considered a good example of a nature-based solution. The objective of the overall concept is to optimally use the natural available materials for the port and coastal protection and as such, it strives to limit its environmental and ecological impact. Due to the unconventional geometry of the breakwater, this port solution is further arguably better in terms of wave sheltering compared with a conventional breakwater.

The solution includes an integrated maintenance and monitoring program to guarantee the safety of the sandbar, navigability of the access channel and to mitigate the retreat at the downdrift side of the port by means of a sand engine. Alongshore sediment transport rates, expected erosion at the downdrift side and maintenance depth of the access channel are important aspects in that respect, which need to be adjusted to each other.

This concept may become a generic port solution in coastal environments like the Gulf of Guinea, with the presence of a relatively uniform wave climate, a sandy coast and a unidirectional longshore transport. The applicability of the concept along other sandy coasts across the globe requires further investigation, although the important criteria for success can already be deduced from the realisation of the Sandbar Breakwater at Lekki, Nigeria.

Although the main principle of the present concept is based on a unidirectional longshore transport, one could think of alternatives of this concept in an environment with multidirectional transports where softer materials, such as sand, form the basis of the port protection. Let the present concept therefore be inspiration for further development of nature-based port solutions.

Author Contributions: Conceptualization, B.J.v.d.S., E.B., B.v.d.S. and D.H.; methodology and design, B.J.v.d.S., E.B., B.v.d.S., D.H. and B.B.; Numerical modelling and validation, S.P., B.B. and B.J.v.d.S.; writing-draft manuscript preparation, B.J.v.d.S.; writing—review and editing, E.B., B.v.d.S., D.H., S.P. and B.B.; visualisation, B.v.d.S. All authors have read and agreed to the published version of the manuscript.

Funding: This research received no external funding. 
Acknowledgments: The authors acknowledge the Dangote Group for their confidence in this nature-based design concept, Boskalis for their professional execution of the works and expert Cypriaan Hendrikse for his contribution to the initial concept development.

Conflicts of Interest: The authors declare no conflict of interest.

\section{Appendix A}

FINEL (FINite ELements) is a hydrodynamic flow model which can operate in the 1D, 2DH, 2DV and 3D modes. Finel has morphological modules to compute the sediment transport and morphological seabed development, both for sand and silt. FINEL is online linked to SwaN to account for wave driven transport. For this study, the FINEL model domain covers a stretch of the Lekki coast of circa $35 \mathrm{~km}$ long and $8 \mathrm{~km}$ wide. The unstructured triangular mesh has a low resolution with a grid size of approximately $500 \mathrm{~m}$ near the seaward model boundaries and a high resolution with a grid size of $7 \mathrm{~m}$ near the coast around the port location. This fine resolution is necessary to get a good representation of the wave driven currents and sediment transport at the steep Lekki breaker zone. Tide driven currents are accounted for by applying TPXO astronomical tidal components [32] on the seaward model boundaries.

Due to the use of a morphological acceleration factor, it is not possible to enforce the actual wave climate onto the Swan model. Instead, a representative wave climate, consisting of a dedicated number of wave conditions that contains the same energy distribution and generates the same amount of sediment transport as the actual wave climate, is applied. In total, 19 wave conditions, each responsible for an equal part of the total longshore transport capacity, are selected. These conditions are divided over 73 different time slots according to their frequency of occurrence. Together, these time slots form the representative wave climate, covering (after the application of a morphological acceleration factor in the computations) two months of seabed development. A subsequent set of six of these cycles represents a full year. Since there is clear seasonal variation in the wave conditions in the area, separate representative wave climates are set up for the rough and calm seasons, each containing three cycles.

Sediment transport is computed using the Soulsby-van Rijn formula [33], with the grain size $\left(\mathrm{D}_{50} / \mathrm{D}_{90}\right)$ based on sediment samples taken in the breaker zone [26]. A maximum bottom slope of $1(\mathrm{~V})$ in $4(\mathrm{H})$ is applied in the model to maintain a representative beach slope and coastline retreat. The morphological model settings are summarised in Table A1.

Table A1. Basic morphological model settings.

\begin{tabular}{ccc}
\hline Parameter & Setting & Unit \\
\hline Grain size $d_{50}$ & 600 & $\mu \mathrm{m}$ \\
Grain size $d_{90}$ & 1100 & $\mu \mathrm{m}$ \\
Pores & 40 & $\%$ \\
Sand density & 2650 & $\mathrm{~kg} / \mathrm{m}^{3}$ \\
Bottom slope factor & 1.6 & - \\
Beta $(\beta)$ & 1 & - \\
Maximum bottom slope & 0.25 & $\mathrm{~m} / \mathrm{m}$ \\
\hline
\end{tabular}

Model calibration is based on satellite images from Google Earth [15] of the project site, taken in January 2016 and May 2016. In this period, two groynes have been built in the area of interest, leading to erosion east of the groynes and sedimentation west of the groynes, see Figures A1 and A2. Since in this period there are no bathymetrical surveys available, the wet-dry boundary of the satellite images is taken as a reference for the morphological calibration, although the water level at the time of the images is unknown. In the model bathymetry, the MSL $-1 \mathrm{~m}$ depth contour is close to the wet-dry boundary of the satellite images, and this contour is therefore used to judge the result of the calibration simulation. 


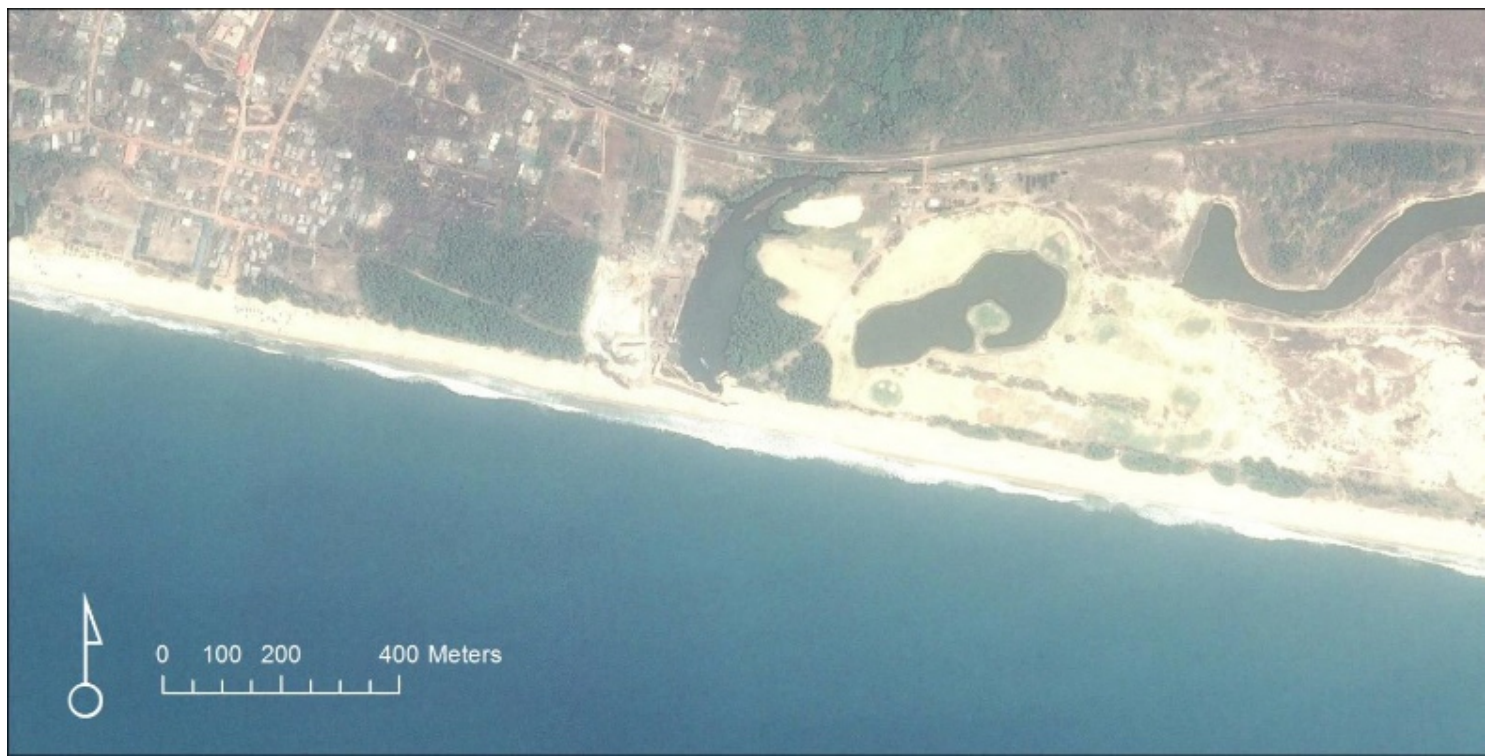

Figure A1. Lekki coast, January 2015.

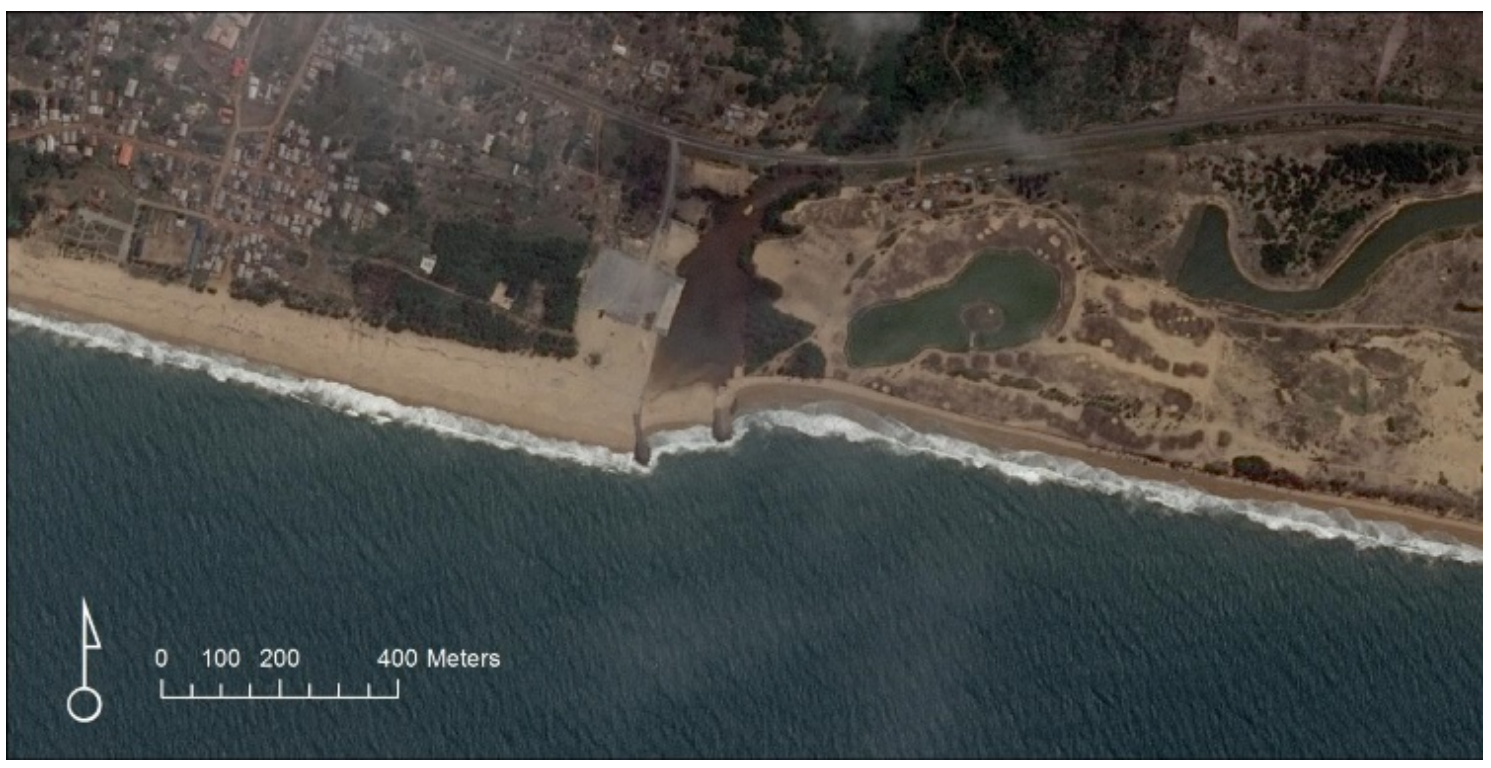

Figure A2. Lekki coast, May 2016.

Applying a slightly increased fall velocity compared with the fall velocity expected, considering the sediment properties, has led to the best coastline development reproduction. The modelled and observed coastline developments correspond well, although some differences are still visible, see Figures A3 and A4. Considering that the pattern and order of magnitude of erosion and sedimentation are similar in the observations and the model, the FINEL-SwAN model is considered a suitable tool to assess the coastline development by human-induced interventions around Lekki. Note that the interpretation of the morphological development by using two satellite images only is also subject to uncertainties. 


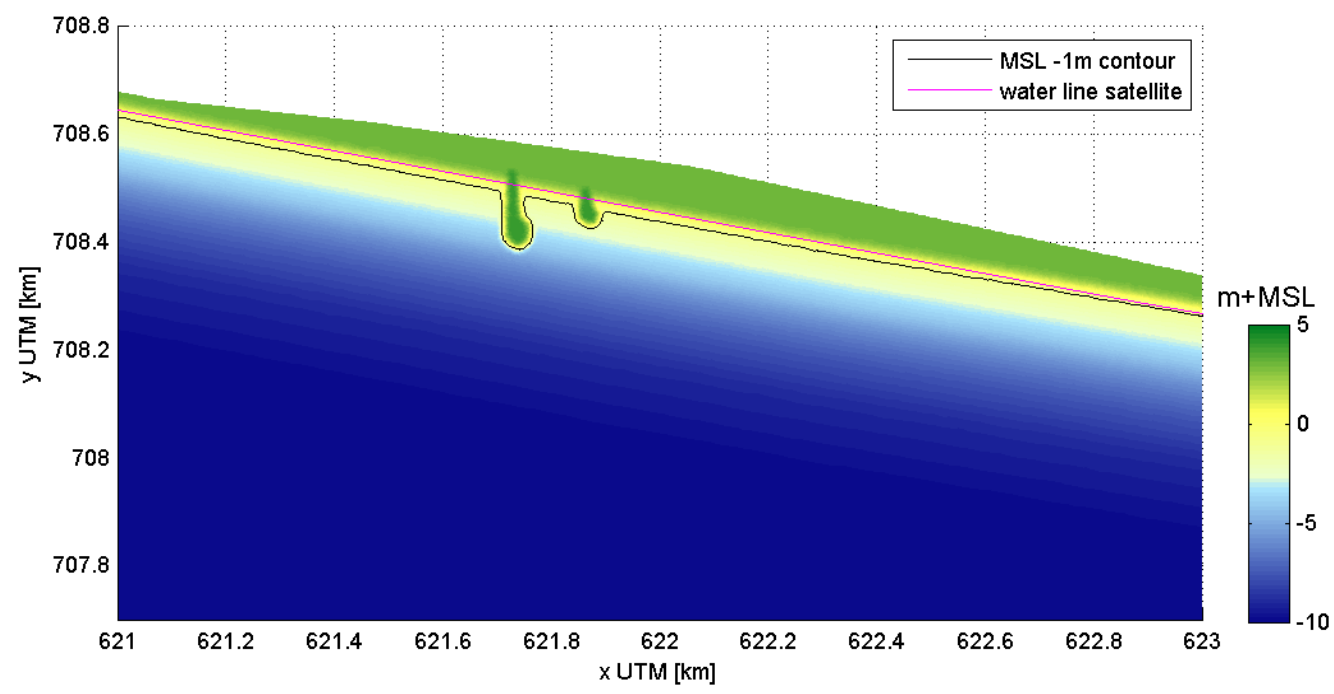

Figure A3. Bathymetry at the start of the calibration simulation.

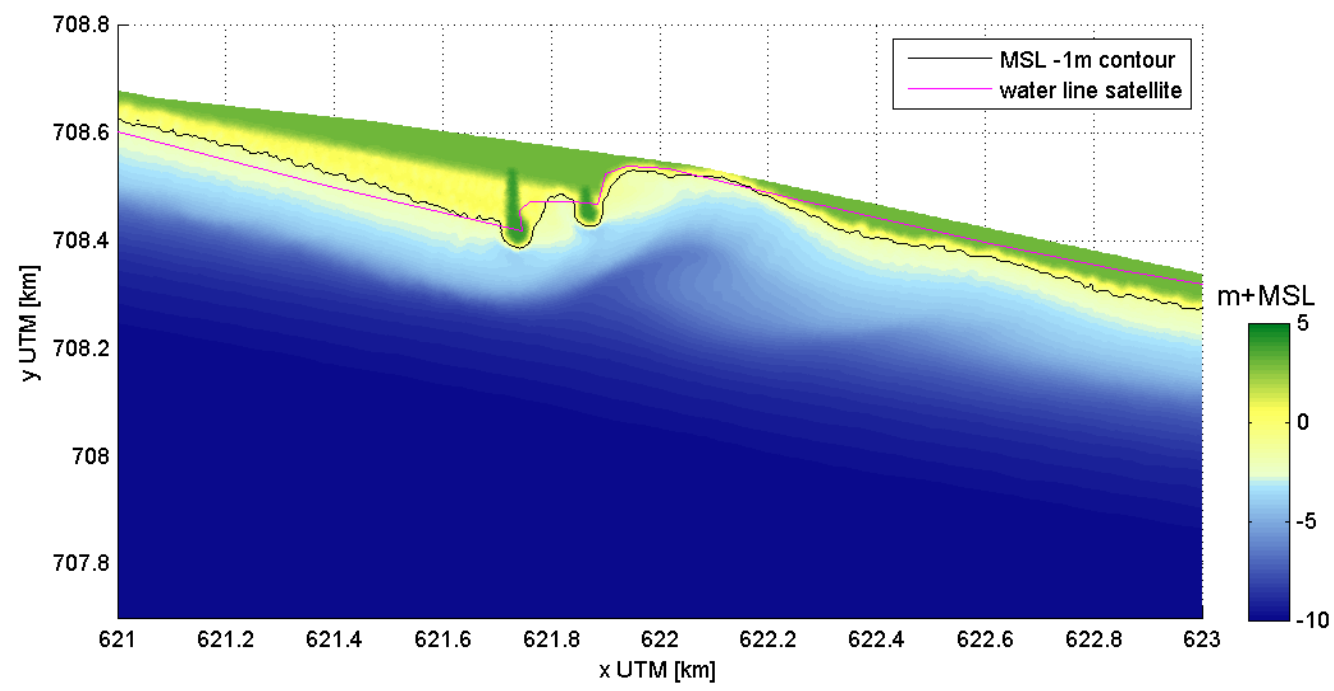

Figure A4. Bathymetry at the end of the calibration simulation.

\section{References}

1. Lawer, E.T. Transitioning Towards Sustainability: Practices and Outcomes in European and West African Ports. Ph.D. Thesis, Universität Bremen, Bremen, Germany, 2019.

2. World Bank. Making the Most of Ports in West Africa; Other Infrastructure Study; World Bank: Washington, DC, USA, 2015.

3. Matz, E. Private Sector \& Development, Proparco. Magazine 2017, 26, 3.

4. Chen, K.; Xu, S.; Haralambides, H. Determining hub port locations and feeder network designs: The case of China-West Africa trade. Transp. Policy 2020, 86, 9-22. [CrossRef]

5. De Boer, W.; Mao, Y.; Hagenaars, G.; de Vries, S.; Slinger, J.; Vellinga, T. Mapping the Sandy Beach Evolution Around Seaports at the Scale of the African Continent. J. Mar. Sci. Eng. 2019, 7, 151. [CrossRef]

6. Giardino, A.; Schrijvershof, R.; Nederhoff, C.; De Vroeg, H.; Brière, C.; Tonnon, P.-K.; Caires, S.; Walstra, D.; Sosa, J.; Van Verseveld, W. A quantitative assessment of human interventions and climate change on the West African sediment budget. Ocean Coast. Manag. 2018, 156, 249-265. [CrossRef]

7. Stocker, T.; Qin, D.; Plattner, G.; Tignor, M.; Allen, S.; Boschung, J.; Nauels, A.; Xia, Y.; Bex, V.; Midgley, P. IPCC, 2013: Summary for Policymakers in Climate Change 2013: The Physical Science Basis, Contribution of Working Group I to the Fifth Assessment Report of the Intergovernmental Panel on Climate Change; Cambridge University Press: Ukny, NY, USA, 2013. 
8. Temmerman, S.; Meire, P.; Bouma, T.J.; Herman, P.M.; Ysebaert, T.; De Vriend, H.J. Ecosystem-based coastal defence in the face of global change. Nature 2013, 504, 79-83. [CrossRef] [PubMed]

9. Stive, M.J.F.; de Schipper, M.A.; Luijendijk, A.P.; Aarninkhof, S.G.J.; van Gelder-Maas, C.; van Thiel de Vries, J.S.M.; de Vries, S.; Henriquez, M.; Marx, S.; Ranasinghe, R. A new alternative to saving our beaches from sea-level rise: The sand engine. J. Coast. Res. 2013, 29, 1001-1008. [CrossRef]

10. Ibe, A. Coastline erosion in Nigeria; The Nigerian Institute for Oceanography and Marine Research: Ibadan, Nigeria, 1988.

11. Van Bentum, K.M. The Lagos Coast-Investigation of the Long-Term Morphological Impact of the Eko Atlantic City Project. Master's Thesis, Delft University of Technology, Delft, The Netherlands, 2012.

12. Wang, Y.; Shen, J.; Zhao, S. Shoreline Evolution and Responses to Port Engineering at Lekki Coast, Nigeria. In Estuaries and Coastal Zones in Times of Global Change; Springer: Berlin/Heidelberg, Germany, 2020; pp. 467-486.

13. Ozer, P.; Hountondji, Y.-C.; De Longueville, F. Erosion Littorale et Migrations Forcées de Réfugiés Environnementaux. L'exemple de Cotonou, Bénin. In Proceedings of the XXVIème Colloque International Association Internationale de Climatologie, Cotonou, Benin, 3-7 September 2013.

14. Anthony, E.J.; Blivi, A. Morphosedimentary evolution of a delta-sourced, drift-aligned sand barrier-lagoon complex, western Bight of Benin. Mar. Geol. 1999, 158, 161-176. [CrossRef]

15. Google Inc. Google Earth Pro. Available online: https://www.google.com/earth/ (accessed on 31 March 2020).

16. Pelnard-Considere, R. Essai de Theorie de L'evolution des Formes de Rivage en Plages de Sable et de Galets; Les Energies de la Mer: Compte Rendu Des Quatriemes Journees de L'hydraulique, Paris 13, 14 and 15 June 1956; Question III, Rapport 1, 74-1-10; Société Hydrotechnique de France: Paris, France, 1956.

17. Kroon, A.; van Leeuwen, B.; Walstra, D.-J.; Loman, G. Dealing with uncertainties in long-term predictions of a coastal nourishment. In Coastal Management: Changing Coast, Changing Climate, Changing Minds; ICE Publishing: London, UK, 2016; pp. 9-18.

18. Dam, G.; Van der Wegen, M.; Labeur, R.; Roelvink, D. Modeling centuries of estuarine morphodynamics in the Western Scheldt estuary. Geophys. Res. Lett. 2016, 43, 3839-3847. [CrossRef]

19. Booij, N.; Holthuijsen, L.; Ris, R. The "SWAN" wave model for shallow water. In Coastal Engineering 1996; American Society of Civil Engineers: Reston, VA, USA, 1996; pp. 668-676.

20. Roelvink, D.; Reniers, A.; Van Dongeren, A.; Van Thiel de Vries, J.; Lescinski, J.; McCall, R. XBeach Model Description and Manual; Report 21 June 2010; Unesco-IHE Institute for Water Education, Deltares and Delft University of Tecnhology: Delft, the Netherlands, 2010.

21. Eikema, B.; Attema, Y.; Talstra, H.; Bliek, A.; de Wit, L.; Dusseljee, D. Spectral modeling of wave propagation in coastal areas with a harbor navigation channel. In Proceedings of the PIANC World Congress, Panama, FL, USA, 7-11 May 2018; pp. 1-16.

22. Construction Industry Research and Information Association; Civieltechnisch Centrum Uitvoering Research en Regelgeving (Netherlands); Centre d'études maritimes et fluviales (France). The Rock Manual: The Use of Rock in Hydraulic Engineering, 2nd ed.; CIRIA: London, UK, 2007; ISBN 0-86017-683-5.

23. British Standard Institution. BS 6349-7: Maritime Structures-Part 7: Guide to the Design and Construction of Breakwaters; BSI Group: London, UK, 1991.

24. Van Gent, M.R. Oblique wave attack on rubble mound breakwaters. Coast. Eng. 2014, 88, 43-54. [CrossRef]

25. Van Rijn, L.C. Longshore sand transport. In Coastal Engineering 2002: Solving Coastal Conundrums; World Scientific: Singapore, 2003; pp. 2439-2451.

26. Copline Engineering Services. Sand Sampling Campaign Lekki-Laboratory Sand Testing and Reporting; Copline Engineering Services: Lagos, Nigeria, 2016.

27. Moesker, N. Sandbar Breakwaters: Analysis of the Effects of Variations in Wave Climate on the Morphological Development of Sandbar Breakwaters by Using the Lekki Sandbar Breakwater Case Study. Master's Thesis, Delft University of Technology, Delft, The Netherlands, 2020.

28. Boswood, P.; Voisey, C.; Victory, S.; Robinson, D.; Dyson, A.; Lawson, S. Beach Response to Tweed River Entrance Sand Bypassing Operations. In Proceedings of the Australasian Coasts and Ports 2005, At Adelaide, South Australia, 20-23 September 2005; A.C.T. Institution of Engineers: Barton, Australia, 2005; p. 119.

29. Grey, S.; Cruickshank, I.; Beresford, P.; Tozer, N. The Impact of Navigation Channels on Berth Protection; Thomas Telford Ltd: London, UK, 2010; Volume 163, pp. 49-54. 
30. Waterman, R.E. Integrated Coastal Policy via Building with Nature, 2nd ed.; Citeseer: The Hague, The Netherlands, 2008; ISBN 978-90-805222-3-7.

31. De Vriend, H.J.; van Koningsveld, M.; Aarninkhof, S.G.; de Vries, M.B.; Baptist, M.J. Sustainable hydraulic engineering through building with nature. J. Hydroenviron. Res. 2015, 9, 159-171. [CrossRef]

32. Egbert, G.D.; Erofeeva, S.Y. Efficient inverse modeling of barotropic ocean tides. J. Atmos. Ocean. Technol. 2002, 19, 183-204. [CrossRef]

33. Soulsby, R. Dynamics of Marine Sands: A Manual for Practical Applications; Thomas Telford: London, UK, 1997; ISBN 0-7277-2584-X.

(C) 2020 by the authors. Licensee MDPI, Basel, Switzerland. This article is an open access article distributed under the terms and conditions of the Creative Commons Attribution (CC BY) license (http://creativecommons.org/licenses/by/4.0/). 